\title{
Fluoride - Seen from Different Perspectives
}

Research on fluoride has played a major role in dental research for more than half a century. The mode of action of fluoride, its pharmacodynamic and pharmacokinetic properties, has been intensively studied. The clinical effects of a broad use of fluoride in different forms have been proven by the low caries prevalence among children and adults in many industrialized countries. However, the current concepts of fluoride use are based on the knowledge developed during periods of time when the caries level in the population was high.

Many questions are, therefore, still open due to a different situation regarding caries in the population. Recent epidemiological data demonstrate that caries appears to be a problem mainly in a relatively small percentage of the population. Such a group is the increasing number of elderly people who often are on medication causing reduced salivation. During the 1990s the decline in caries among children and adolescents has leveled off. Lower awareness of the importance of frequent fluoride exposure in combination with proper oral hygiene and an increasing consumption of acidic soft drinks have been noticed among adolescents.

In the light of these changing conditions, a workshop 'Fluoride - Seen from Different Perspectives' was initiated and successfully organized by GABA International. The aim of the workshop was to sum up the knowledge on fluoride, and to define research needs and future perspectives for fluoride use and application. Recent progress in the understanding of the mechanism of action of fluoride, individual targeting of caries prevention, new diagnostic techniques, new development of slow release devices, the need for standardized guidelines for conducting clinical trials, as well as the need for more sensitive caries indices were among the topics presented.

The opportunity to have the proceedings of the workshop published in this special issue of Caries Research is greatly appreciated.

Bjørn Øgaard, University of Oslo

\begin{tabular}{ll}
\hline KARGER & (c) 2001 S. Karger AG, Basel \\
0008-6568/01/0357-0001\$17.50/0 \\
$\begin{array}{l}\text { Fax +4161306 12 34 } \\
\text { E-Mail karger@karger.ch } \\
\text { www.karger.com }\end{array}$ & $\begin{array}{l}\text { Accessible online at: } \\
\text { www.karger.com/journals/cre }\end{array}$
\end{tabular}

